\title{
<증례보고>
}

\author{
한우 집단 폐사를 유발한 엔도설판 중독 사례 \\ 이보람 ${ }^{1} \cdot$ 이현경 ${ }^{1} \cdot$ 이경현 ${ }^{1} \cdot$ 윤순식 $^{1} \cdot$ 김미경 ${ }^{1} \cdot$ 박중원 $^{1} \cdot$ 정선향 $^{2} \cdot$ 이명헌 $^{1} \cdot$ 배유찬 $^{1 *}$ \\ 1농림축산검역본부 질병진단과, ${ }^{2}$ 경기도축산위생연구소 \\ (접수: 2013년 9월 16일, 게재승인: 2013년 10월 25일)
}

\section{Devastating endosulfan poisoning in Korean native cattle}

\author{
Bo-ram Lee ${ }^{1}$, Hyun-Kyoung Lee ${ }^{1}$, Kyung-Hyun Lee ${ }^{1}$, Soon-Seek Yoon ${ }^{1}$, Meekyung Kim ${ }^{1}$, \\ Jung-Won Park ${ }^{1}$, Seon-Hyang Jeong ${ }^{2}$, Myoung-Heon Lee ${ }^{1}$, You-Chan Bae ${ }^{1, *}$ \\ ${ }^{1}$ Animal Disease Diagnostic Division, Animal and Plant Quarantine Agency, Anyang 430-757, Korea \\ ${ }^{2}$ Gyeonggido Veterinary Service, Suwon 441-460, Korea \\ (Received: September 16, 2013; Accepted: October 25, 2013)
}

\begin{abstract}
Here, we report the poisoning case of 10 cows. Several distinct clinical signs such as convulsion, excessive salivation, circling, lateral recumbency, and death were observed. Necropsy and histopathological examination did not reveal any significant abnormal findings. Moreover, no bacteria or viruses were detected in tissue, blood, and feeding food. However, endosulfan was detected from the stomach contents and microbials. Our results strongly suggest that death of cows may be closely associated with endosulfan poisoning.
\end{abstract}

Keywords : cattle, endosulfan, neurological sign, pesticide, poisoning

엔도설판(endosulfane)은 1940년대부터 1970년대 중반까지 널리 사용된 유기염소계 살충제로 지오릭스(Thiolix), 티오단 (Thiodan), 시클로단(Cyclodan) 등의 상품명으로 알려져 있으 며 살응애제, 살충제 등의 용도로 쓰이는 농약이다. 급성 독 성을 일으키는 고독성 농약으로 환경 중에 잔류기간이 길고 체내에 축적되어 현재는 사용이 제한되고 있다 [4].

엔도설판 단기독성시험에서 실험동물은 과다흥분, 떨림, 경 련 등과 같은 신경 증상들을 나타내거나 사망했다. 또한 치 사량이나 준치사량의 엔도설판을 투여했을 때, 폐와 심장의 조절기능 이상뿐 아니라 위, 간, 신장 등에 독성을 나타냈다. 또한 엔도설판은 흡입, 경구, 피부를 통하여 흡수되는 것으 로 확인되었으며 경구 투여한 엔도설판은 $80 \%$ 정도 흡수된 반면 피부를 통하여 투여한 엔도설판은 $20 \%$ 정도 흡수되었 다 [1].

소의 엔도설판 중독 사례는 외국에서 다수 보고되었으나 국내에서는 보고가 드문 상황이다. 본 사례에서는 한우를 사 육하는 목장에서 엔도설판 중독에 의한 집단 폐사가 발생하 여 이에 대해 보고하고자 한다.

2012년 11월 11일과 12일, 경기도 이천시 율면에 소재한 한우 40 여 두를 키우는 농장에서 이틀 동안 건강하던 한우
성우 10 두가 발작과 함께 눈꺼풀과 안면 근육의 간헐적 경 련, 과다 유연(Fig. 1A), 선회 및 뒷걸음질 치는 행동을 보 이며 횡와 후 급사하였다. 농림축산검역본부 질병진단과 직 원들과 경기도 축산위생연구소 방역관들이 농장에 출장하여 역학조사와 부검을 실시하였다. 기립불능우(생축) 1 두와 폐 사우 2 두 총 3 두를 부검하였다. 3 두 모두 장기 내 특이한 소견은 확인되지 않았으며, 1 위 내에는 다량의 조사료와 농 후사료가 들어 있었다(Fig. 1B). 또한 생축 1두에서 위점막 의 발적소가 관찰되었다.

주요 내부 장기는 병리조직학적 검사를 위하여 $10 \%$ 중성 포르말린에 충분히 고정시킨 후 통상적인 조직처리과정을 거 친 다음 파라핀에 포매하였다. 파라핀 포매 블록을 약 2.5 $\mu \mathrm{m}$ 의 두께로 절편한 조직은 hematoxylin and eosin $(\mathrm{H} \& \mathrm{E})$ 염색을 실시하여 광학현미경 하에서 관찰하였다. 또한 위 내 용물, 사료(성우 비육 사료, 송아지 농후 사료, 등겨, 볏짚, 배추) 및 미생물제제 등과 같은 환경시료에 대한 농약검사를 함께 실시하였다. 농약 검사는 시료 전처리 및 기기 분석의 순서로 진행되었으며 기기 분석에는 기체크로마토그래프 (7890A GC/FPD; Agilent Technologies, USA), 기체크로마 토그래프/질량분석기(6890N GC/MSD; Agilent Technologies)

\footnotetext{
*Corresponding author

Tel: +82-31-467-1758, Fax: +82-31-467-1780

E-mail: kyusfather@korea.kr
} 

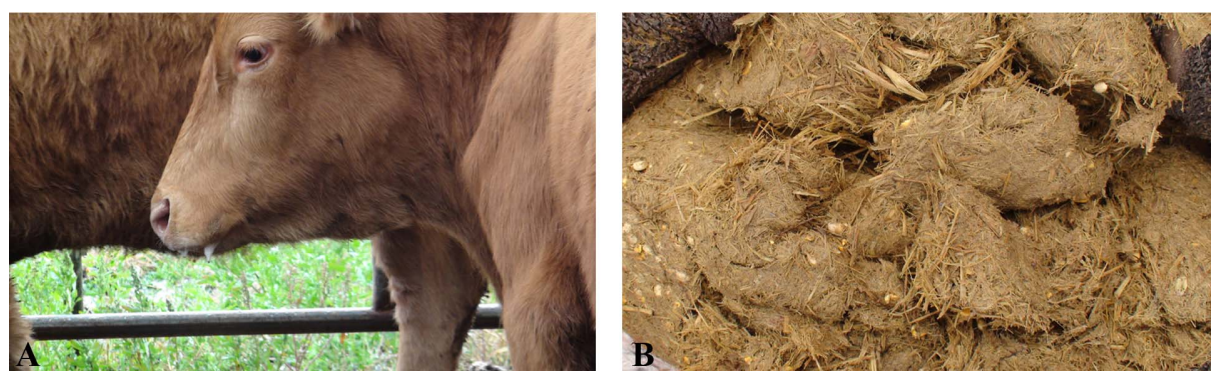

Fig. 1. (A) Note the excessive salivation around mouth. (B) Excessive concentrated feed and roughage in rumen.

Table 1. Analysis for pesticides in samples

\begin{tabular}{lcc}
\hline \hline Samples & Pesticides & Concentration $(\mathrm{mg} / \mathrm{kg})$ \\
\hline Stomach contents 1 & Endosulfan & 15.90 \\
Stomach contents 2 & Endosulfan & 31.41 \\
Stomach contents 3 & Endosulfan & 44.34 \\
Stomach contents 4 & Endosulfan & 3.04 \\
Microbials & Endosulfan & 0.42 \\
Feed & - & - \\
Water & - & - \\
\hline
\end{tabular}

가 사용되었다. 이 외에도 혈액 검사, 주요 내부 장기 및 혈 액을 이용한 바이러스 검사 및 세균 검사, 환경시료에 대한 세균 검사를 실시하였다.

병리조직학적 관찰 결과 생축 1 두에서 경미한 간세포의 변 성 및 괴사가 관찰되었을 뿐 기타 장기에서는 특이소견이 관 찰되지 않았다. 농약분석 결과 위 내용물에서 개체에 따라 $3.04 \sim 44.3 \mathrm{mg} / \mathrm{kg}$ 의 엔도설판이 검출되었으며, 미생물제제에 서도 $0.42 \mathrm{mg} / \mathrm{kg}$ 의 엔도설판이 검출되었고 나머지 시료에서 는 검출되지 않았다(Table 1, Fig. 2). 혈청화학검사 상 개체 간의 차이는 있지만 공통적으로 $\mathrm{CPK}$ 가 상승해 있었으며 (101 2,000 U/L 이상, Normal range: 98 120 U/L) 경우에 따라 GOT의 상승도 확인할 수 있었다 $(233 \sim 1,000 \mathrm{U} / \mathrm{L}$ 이
상, Normal range: 78 132 U/L). 바이러스 및 세균 검사 결과는 모두 음성이었다. 이상의 결과를 토대로 엔도설판 중 독증으로 최종진단 되었으며 진단 이후 추가 발생은 확인되 지 않았다.

엔도설판의 반치사량(LD50)은 마우스에서는 $13.5 \sim 35 \mathrm{mg}$ / $\mathrm{kg}$, 랫드에서는 $9.6 \sim 160 \mathrm{mg} / \mathrm{kg}$, 개의 경우 $77 \mathrm{mg} / \mathrm{kg}$ 이지만 소에서는 정확하게 알려진 바가 없다. 한 문헌에 따르면 소 에서 $8 \mathrm{~g}$ 의 엔도설판을 구강투여 하거나 $0.01 \%$ 의 엔도설판 액을 체표면에 분사할 경우 폐사를 일으킬 수 있다고 한다 $[1,3]$. 엔도설판은 간이나 신장을 통하여 대사 및 배설 되는 것으로 알려져 있으며 중독된 소들의 간과 신장에서 엔도설 판이 검출되었다 [6].

소에서 엔도설판 중독증은 과거에 터키와 미국 등지에서 외부기생충 구제를 위한 엔도설판액의 직접적인 체표 도포 에 의하여 발생한 바 있다 [2, 3]. 또한 미국에서는 1994년 에 목부의 사육 미숙으로 인하여 소들이 엔도설판, 다이엘드 린, 디디티 그리고 디디이의 합제로 만들어진 농약병에 접근 하여 중독으로 급사한 경우도 있다 [5]. 이러한 가축의 농약 중독은 직접적으로 농가의 경제적 손실을 일으키며, 더 나아 가서 축산물의 오염에 따른 공중보건학적인 문제로 직결된 다. 2008년에 뉴질랜드산 수입 쇠고기에서 엔도설판의 잔류 농도가 기준치보다 높게 확인되어 큰 사회적인 문제로 대두 되었으며 1999년과 2005년에도 호주와 뉴질랜드 등지에서

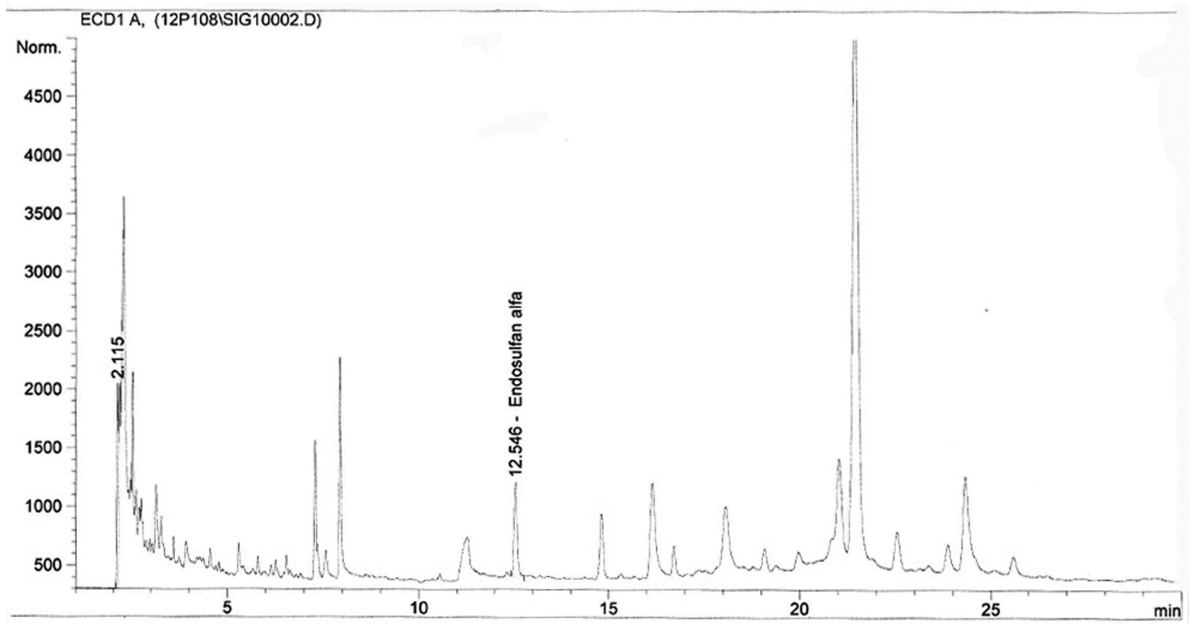

Fig. 2. Chromatogram of microbials. Endosulfan alpha was found from microbials. 
수입되는 쇠고기에서 엔도설판의 농도가 높게 측정된 바가 있다. 역학조사 결과 이들 모두 소의 방목지 주변에서 엔도 설판을 살포하여 오염된 것으로 추정되었다. 이와 같이 엔도 설판의 경우 주변 작물을 보호하기 위하여 흔하게 쓰여온 농 약제제이지만, 가축의 중독 및 오염의 원인이 되어 왔다. 2011년 4월에 스위스 제네바에서 열린 “잔류성유기오염물질 (POPs)에 관한 스톡홀름협약 제 5 차 당사국총회"에서 엔도설 판을 협약 대상물질로 규정키로 합의하여 국내에서도 엔도 설판의 생산, 판매 및 수출이 전면 금지되었다.

본 사례에서 나타난 근육 경련, 선회 운동, 과다 유연 등 은 기존의 엔도설판 중독사례와 일치하였다 [3]. 엔도설판 중 독과 감별할 질병으로는 보툴리즘, 유열 등이 있는데 보툴리 즘의 경우 신경증상이 없고 마비가 주된 증상이므로 본 사 례와는 구별이 된다. 본 사례의 경우, 위 내용물과 미생물제 제에서 엔도설판이 각각 검출되었다. 미생물제제는 사료에 혼합하여 급여되며 가축의 성장촉진 혹은 치료 목적으로 사 용되는 항생제, 항균물질의 대안으로 이용되는 생균제로서 가축의 생산성 향상 또는 설사예방 등의 효과를 기대할 수 있다 [7]. 본 사례에서는 미생물제제와 위 내용물에서 동일 하게 엔도설판이 검출되었지만 급여 사료 등의 기타 환경시 료에서는 엔도설판이 검출되지 않았다. 따라서 미생물제제가 엔도설판에 오염되어 사료 내로 유입됨에 따라 중독되었을 것으로 예측된다.

본 사례의 경우 미생물제제가 어떠한 경로로 엔도설판에 오염되었는지 정확한 경로는 파악하기 힘들다. 다만, 이미 사 용 금지된 농약이므로 판매가 중단되기 전에 구입한 엔도설 판에 오염되었을 가능성이 높다고 생각한다. 또한, 엔도설판 은 공기, 물, 토양에 잔류 가능성이 높은 약품으로 작물에 분사하였을 경우 주변의 농토 및 수로 등에도 영향을 미칠 수 있다 [6]. 그러므로 본 사례에서는 미생물제제의 제조나 보관 등에 있어서 주변에 잔류했던 엔도설판에 의한 오염 가 능성을 배제할 수 없다. 특히 우사와 인접한 곳에, 비교적 살충제의 쓰임이 많은 과수원이 존재하였으므로 이에 대한 추가적인 역학조사가 필요하다.
본 사례는 한우에서 발작 및 경련 등의 임상증상을 나타 내며 집단 폐사한 엔도설판 중독증 사례로 국내 수의학계에 서는 처음으로 정식 학술 보고된 사례이다. 병리조직, 세균, 바이러스 검사 등에서 특이소견은 없었으나, 임상증상 및 위 내용물과 환경시료 등의 농약 분석을 통하여 엔도설판 중독 증을 확진 할 수 있었다. 이번 사례를 교훈으로 삼아 농약이 미생물제제 등 다른 물질에 접촉되지 않도록 주의를 기울여 서 가축의 피해를 예방해야 할 것으로 생각한다. 또한 본 사 례가 소에서 집단적으로 신경증상과 폐사를 나타내는 질병 의 감별진단에 도움이 되기를 바란다.

\section{감사의 글}

농장에서 역학조사를 해주신 경기도축산위생연구소 최권락 팀장님을 비롯한 관계자들께 감사드립니다.

\section{References}

1. Agency for Toxic Substances and Disease Registry (ATSDR). Toxicological profile for Endosulfan. (Draft for Public Comment), pp. U.S. Department of Health and Human Services, Public Health Service, Atlanta, 2000.

2. Kelch WJ, Kerr LA. Acute toxicosis in cattle sprayed with endosulfan. Vet Hum Toxicol 1997, 39, 29-30.

3. Mor F, Ozmen O. Acute endosulfan poisoning in cattle. Vet Hum Toxicol 2003, 45, 323-324.

4. Park KR, Jung YS, Rim H. A case of endosulfan intoxication with pulmonary embolism. Korean J Med 2008, 74, 250-253.

5. Smith RA, Tramontin RR. Cattle poisoning by a mixture of endosulfan, dieldrin, DDT and DDE. Vet Hum Toxicol 1995, 37, 470-471.

6. 식품의약품안전청 위해예방정책과. 유해물질 총서 54 엔도 설판, 식품의약품안전청, 청원, 2010.

7. 지형진, 서장선, 양동수, 박경석, 허성기, 이윤정, 이상엽, 김정준, 김동운, 이숭돈, 정구복. 농업미생물 현장활용 매 뉴얼, 농촌진흥청, 수원, 2009. 